\title{
Menetapkan Pilihan Nilai Jual Obyek Pajak Bumi dan Bangungan sebagai Dasar Penghitungan Bea Perolehan Hak atas Tanah dan Bangunan*)
}

\author{
R. Murjiyanto dan Samun Ismaya \\ Fakultas Hukum Universitas Janabadra \\ Jln. Timoho II/40 Yogyakarta \\ rmurjiya@yahoo.com, samunismaya@gmail.com
}

\begin{abstract}
Fee for Acquisition of Land and Building (BPHTB) is an obligatory fee that must be paid by any parties receiving rights over land and building. In order to get certainty in paying BPHTB, it is necessary to change the values used as the standard in calculating BPHTB. This research discusses: first, what is the difference of transaction value gap with (NJOP PBB) in SPPT PBB? Second, what values that can be selected to be used as the standard of calculating BPHTB? This research was conducted using normative method supported by primary data. The findings conclude that: first, transaction values are generally higher than NJOP PBB written in SPPT PBB. Second, in order to gain certainty in the payment of BPHTB, it is necessary to set a reasonable value in NJOP PBB as written in SPPT PBB to be used as a standard in calculating BPHTB.
\end{abstract}

Keywords: Cost, calculating, rights over land and building

\begin{abstract}
Abstrak
Bea Perolehan Hak Atas Tanah dan Bangunan (BPHTB) adalah kewajiban yang harus dibayar oleh pihak yang memperoleh hak atas tanah dan bangunan. Dalam rangka memperoleh kepastian dalam pembayaran BPHTB, maka perlu dilakukan perubahan tentang nilai yang digunakan sebagai dasar menghitung BPHTB. Penelitian ini mengkaji: pertama, bagaimana perbedaan rentang nilai transaksi dengan (NJOP PBB) dalam SPPT PBB? Kedua, nilai apakah yang dapat dipilih untuk ditetapkan sebagai dasar penghitungan BPHTB? Penelitian ini dilakukan dengan metode normatif yang didukung dengan data primer. Hasil penelitian ini menyimpulkan: pertama, nilai transaksi pada umumnya lebih tinggi dari NJOP PBB yang tercantum dalam SPPT PBB. Kedua, agar terdapat kepastian dalam pembayaran BPHTB, perlu ditetapkan nilai yang wajar pada NJOP PBB yang tercantum dalam SPPT PBB untuk digunakan sebagai dasar penghitungan BPHTB.
\end{abstract}

Kata Kunci: Bea, penghitungan, hak atas tanah dan bangunan

*) Makalah Hasil Penelitian Hibah Bersaing yang Didanai Oleh Direktorat Jenderal Pendidikan Tinggi Kementerian Pendidikan Dan Kebudayaan RI Tahun 2015 


\section{Pendahuluan}

Pada awalnya dasar pengenaan Bea Perolehan Hak atas Tanah dan Bangunan (BPHTB) diatur Undang-Undang No. 21 Tahun 1997 tentang Bea Perolehan Hak Atas Tanah dan Bangunan, yang telah dirubah dengan UndangUndang No. 20 Tahun 2000 tentang Perubahan Undang-Undang No. 21 Tahun 1997 tentang Bea Perolehan Hak Atas Tanah dan Bangunan yang kemudian disebut UU BPHTB, yang semula sebagai pajak pemerintah pusat. Kemudian seiring dengan perkembangan dikeluarkan Undang-Undang Nomor 28 Tahun 2009 tentang Pajak Daerah dan Retribusi Daerah atau UU PDRD yang di dalamnya antara lain mengatur tentang Bea Perolehan Hak Atas Tanah dan Bangunan (BPHTB). Dengan berlakunya UU PDRD tersebut maka BPHTB merupakan pajak daerah ${ }^{1}$, yang pengelolaan dan pemungutannya diserahkan kepada daerah sesuai dengan pemberian otonomi kepada daerah. ${ }^{2}$ Pada era otonomi daerah dewasa ini, ada kewenangan mengenai pajak yang telah dialihkan atau diserahkan oleh pemerintah pusat kepada daerah. ${ }^{3}$

Dari awal pelaksanaan pengenaan BPHTB tersebut hingga saat ini menimbulkan permasalahan bagi masyarakat yang melakukan perbuatan hukum peralihan hak atas tanah, khususnya jual beli. Salah satu hal yang menimbulkan permasalahan adalah, bahwa ketentuan tentang dasar yang digunakan sebagai dasar perhitungan BPHTB baik yang diatur dalam UU BPHTB maupun dalam UU PDRD adalah dengan menggunakan nilai transaksi. Nilai transaksi adalah nilai yang merupakan kesepakatan antara para pihak yang melakukan transaksi, seperti kalau dalam jual beli, adalah antara penjual dengan pembeli. Kepastian hukum nilai transaksi turut dalam menentukan sah tidaknya sebuah jual beli, dalam hal ini apakah benar bahwa nilai transaksi baik yang dicantumkan dalam akta jual beli maupun yang digunakan sebagai dasar perhitungan BPHTB adalah benar-benar

1 Adrian Sutedi, Hukum Pajak dan Retribusi Daerah, Ghalia Indonesia, Bogor 2008, hlm. 57, bahwa pajak daerah adalah pajak negara yang diserahkan kepada daerah untuk dipungut berdasarkan peraturan perundangundangan, yang dipergunakan guna membiayai pengeluaran daerah sebagai badan hukum publik.

2 Murtir Jeddawi, Implementasi Kebijakan Otonomi Daerah (Analisis Kewenangan, Kelembagaan, Managemen Kepegawaian, dan Peraturan Daerah), Total Media, Yogyakarta, 2008, bahwa otonomi daerah mengandung arti kemandirian untuk mengatur dan mengurus rumah tangganya sendiri.

${ }^{3}$ Priyo Katon Prasetyo, "Interaksi Kepentingan Dalam Penentuan Bea Perolehan Hak Atas Tanah", Jurnal Agraria dan Pertanahan, Volume 1, No. 1, 2015, hlm. 75 
sesuai dengan kenyataan yang telah disetujui atau disepakati oleh pihak-pihak yang melakukan transaksi.

Dengan penggunaan nilai transaksi sebagai dasar perhitungan ВРНТВ inilah yang sering kali menimbulkan permasalahan dilapangan, karena tidak jarang nilai transaksi yang diajukan oleh wajib pajak dianggap tidak sesuai oleh petugas pajak, sehingga tidak jarang petugas pajak dalam proses verifikasi/validasi, meminta agar nilai transaksi dirubah dan disesuaikan menurut penilaian petugas pajak. Hal ini dapat terjadi karena pada umumnya orang berkeinginan agar pajaknya ringan, sehingga nilai yang dicantumkan dalam akta dan yang digunakan sebagai dasar perhitungan BPHTB tidak sesuai dengan kenyataan yang sebenarnya. Demikian juga sebaliknya petugas pajak menginginkan pajak yang dibayar harus sesuai dengan harga pasar yang cenderung jauh lebih tinggi dari Nilai Jual Obyek Pajak Bumi dan Bangungan (NJOP PBB). Petugas pajak dalam menentukan nilai transaksi yang sebenarnya tidaklah mudah, karena biasanya hanya diperoleh dari berbagai data dan informasi dan tidak ada ukuran yang pasti, tidak menutup kemungkinan nilai transaksi yang ditentukan oleh petugas pajak ini justru tidak sesuai dengan kenyataan yang sebenarnya.

Dari gambaran tersebut, maka nilai transaksi baik yang diajukan oleh wajib pajak yang dimuat dalam akta dan sebagai dasar perhitungan BPHTB dan yang ditentukan oleh petugas pajak dalam validasi, adalah bersifat relatif dan subyektif, sehingga dapat menimbulkan ketidakpastian. Ketidakpastian ini dapat menimbulkan berbagai konsekuensi hukum, antara lain, dapat mengakibatkan transaksinya menjadi tidak sah dan bahkan menjadi batal. Bahkan tidak menutup kemungkinan dapat merugikan masyarakat, karena harus membayar pajak yang lebih tinggi dari yang seharusnya. Di samping itu juga menimbulkan prosedur yang rumit dan panjang, karena diperlukan proses validasi yang kadang memakan waktu yang lama. Berdasarkan hal tersebut, maka perlu dikaji secara mendalam mengenai nilai yang tepat dan pasti sebagai dasar penghitungan pengenaan BPHTB yang harus dibayar oleh masyarakat yang melakukan peralihan hak atas tanah.

Dari hasil penelitian pada tahun pertama diperoleh beberapa alternatif nilai yang dapat ditetapkan sebagai dasar penghitungan BPHTB, baik yang ditetapkan oleh Kantor Pertanahan, atau pemerintah daerah melalui dinas yang berwenang 
atau oleh KPP Pratama, maupun nilai jual obyek pajak yang tercantum dalam surat pemberitahuan pajak terutang pajak bumi dan bangunan (SPPT PBB). Dalam memilih alternatif nilai tersebut perlu dikaji nilai mana yang seharusnya ditetapkan sebagai dasar penghitungan BРHTB dengan pertimbangan-pertimbangan yang wajar, dengan melakukan perubahan undang-undang dan kemudian diikuti dengan peraturan pelaksanaannya melalui peraturan daerah masing-masing.

\section{Rumusan Masalah}

Berdasarkan uraian tersebut, maka permasalahan dalam penelitian ini, pertama: bagaimana perbedaan rentang nilai traksaksi dengan nilai NJOP dalam SPPT PBB? Kedua, nilai apakah yang dapat dipilihuntuk ditetapkan sebagai dasar penghitungan BPHTB?

\section{Tujuan Penelitian}

Berdasarkan rumusan masalah yang dirumuskan tersebut, maka penelitian ini bertujuan: untuk mengkaji perbedaan rentang nilai traksaksi dengan nilai NJOP dalam SPPT PBB. Kedua, untuk mengetahui nilai yang dapat dipilih untuk ditetapkan sebagai dasar penghitungan BPHTB.

\section{Metode Penelitian}

Penelitian ini merupakan penelitian normatif (legal research) ${ }^{4}$ atau penelitian doktriner, juga disebut sebagai penelitian kepustakaan atau studi dokumen. Penelitian hukum doktriner merupakan penelitian yang dilakukan atau ditujukan hanya pada peraturan-peraturan yang tertulis atau bahan-bahan hukum yang lain. ${ }^{5}$ Serta dengan mengkombinasikan data primer di lapangan baik dari responden maupun nara sumber. Perolehan data dari penelitian lapangan dilakukan baik

\footnotetext{
${ }^{4}$ Bambang Waluyo, Penelitian Hukum Dalam Praktek, Sinar Grafika, Jakarta, 1991, hlm. 17.

${ }^{5}$ Suratman, dan Philips Dillah, Metode Penelitian Hukum, Dilengkapi Tata Cara \& Contoh Penulisan Karya Ilmiah Bidang Hukum, Alfabeta, Bandung, 2013, hlm. 51
} 
melalui pengamatan (observasi), wawancara ataupun penyebaran kuesioner6, dengan responden yang diambil secara acak yaitu: masyarakat, PPAT dan di dukung dari nara sumber yaitu dari Pejabat Kantor Dinas Kabupaten Bantul, Kabupaten Sleman, dan Kota Yogyakarta yang mengelola BPHTB, dan Pejabat Kantor Pertanahan Kabupaten Bantul, Kabupaten Sleman, dan Kota Yogyakarta.

Data dan keterangan yang diperoleh dari lapangan, baik melalui penggunaan daftar pertanyaan dan wawancara kepada responden maupun nara sumber, maupun dari studi kepustakaan kemudian direduksi dengan mendasarkan pada upaya untuk menjawab permasalahan dan tujuan penelitian yang diajukan. Data yang sudah direduksi sesuai dengan pokok masalah dan didukung dengan peraturan perundang-undangan yang berlaku selanjutnya direkonstruksi dengan pendekatan kualitatif ke dalam uraian diskriptif kualitatif dan akhirnya diambil kesimpulan.

\section{Hasil Penelitian dan Pembahasan}

\section{Pengenaan Bea Perolehan Tanah dan Bangunan (BPHTB) dalam Peralihan Tanah}

Pengenaan Bea Perolehan Hak atas Tanah dan Bangunan (BPHTB) telah berlangsung sejak diberlakukannya Undang-Undang No. 21 Tahun 1997 tentang Bea Perolehan Hak Atas Tanah dan Bangunan, yang dikenakan bagi pihak baik perseorangan maupun badan hukum yang memperoleh hak atas tanah dan bangunan. Seseorang atau badan hukum dapat memperoleh hak atas tanah dan bangunan dapat berasal dari beberapa sebab, antara lain karena jual beli, hibah, warisan, tukar menukar dan lain-lain. Jual-beli sebagai salah satu sebab seseorang memperoleh hak atas tanah dan bangunan pada hakekatnya sebagai perbuatan pengalihan hak kepada pihak/ orang lain dari penjual kepada pembeli. ${ }^{7}$ Dengan memperoleh hak atas tanah dan bangunan maka pihak yang memperoleh hak tersebut dikenakan pajak yang disebut Bea Perolehan Hak Atas Tanah dan Bangunan atau BPHTB, baik diperoleh karena jual beli, hibah, hibah wasiat atau

${ }^{6}$ Ibid., hlm. 53.

${ }^{7}$ Harun Al Rashid, Sekilas Tentang Jual Beli Tanah (Berikut Peraturan-peraturannya), Ghalia Indonesia, Jakarta, 1987, hlm. 50. 
warisan, tukar menukar atau perolehan lainnya yang menjadi obyek BPHTB sesuai dengan ketentuan undang-undang.

Di dalam Pasal 1 Undang-Undang No. 28 Tahun 2009 tentang Pajak Daerah dan Retribusi Daerah maupun Pasal 1 Undang-Undang Nomor 21 Tahun 1997 tentang Bea Perolehan Hak atas Tanah dan Bangunan sebagaimana telah diubah dengan UU No. 20 Tahun 2000 tentang Bea Perolehan Hak Atas Tanah dan Bangunan dijelaskan bahwa "Perolehan Hak atas Tanah dan/atau Bangunan adalah perbuatan atau peristiwa hukum yang mengakibatkan diperolehnya hak atas tanah dan atau bangunan oleh orang pribadi atau badan". Menurut kedua undang-undang tersebut, yang dimaksud dengan Bea Perolehan Hak atas Tanah dan Bangunan atau BPHTB adalah pajak atas perolehan hak atas tanah dan/atau bangunan. Perolehan hak karena perbuatan hukum adalah perolehan hak yang disebabkan karena perbuatan hukum peralihan hak, seperti jual beli, tukar menukar, hibah, pemasukan dalam perusahaan dan perbuatan hukum pemindahan hak lainnya. Sementara itu, perolehan hak karena peristiwa hukum adalah perolehan hak terjadi karena hukum, yang disebabkan karena suatu peristiwa hukum tertentu, seperti meninggalnya pemegang hak, maka ahli waris yang berhak memperoleh hak karena hukum, tanpa ada perbuatan hukum tertentu. ${ }^{8}$

Dalam penjelasan lain, bahwa Perolehan Hak atas Tanah dan/atau Bangunan adalah perbuatan atau peristiwa hukum yang mengakibatkan diperolehnya hak atas tanah dan/atau bangunan oleh orang pribadi atau Badan, sedangkan yang dimaksud dengan Bea Perolehan Hak atas Tanah dan Bangunan atau BPHTB adalah pajak atas perolehan hak atas tanah dan/atau bangunan. ${ }^{9}$

Subjek BPHTB adalah orang pribadi atau badan yang memperoleh hak atas tanah dan bangunan. Subjek pajak yang dikenakan kewajiban membayar pajak menjadi Wajib Pajak (WP) BPHTB. Sebagaimana di Indonesia dikenal subjek hak dapat dimiliki oleh orang pribadi maupun badan hukum. Orang pribadi adalah manusia sebagai orang perseorangan yang dapat memperoleh suatu hak seperti hak atas tanah, sedangkan badan hukum adalah segala sesuatu yang dapat

8 Boedi Harsono, Hukum Agraria Indonesia, Djambatan, Jakarta, 2000, hlm 506-519.

${ }^{9}$ Lihat Undang-Undang No. 28 Tahun 2009 tentang Pajak Daerah dan Retribusi Daerah (Tambahan Lembaran Negara Republik Indonesia Nomor 5049). 
mempunyai hak dan kewajiban, dapat melakukan perbuatan hukum, dapat menjadi subjek hukum, memiliki harta kekayaan dan tanggungjawab sendiri yang terpisah dari orang perseorangan.

Menurut Pasal 85 Undang-Undang No. 28 Tahun 2009 tentang Pajak Daerah dan Retribusi Daerah atau UU PDRD, objek BPHTB adalah perolehan hak atas tanah dan atau bangunan. Hal tersebut sama seperti yang dijelaskan pada Pasal 2 Undang-Undang No. 21 Tahun 1997 tentang Bea Perolehan Hak atas Tanah dan Bangunan sebagaimana telah diubah dengan UU No. 20 Tahun 2000 Tentang Perubahan Undang-Undang No. 21 Tahun 1997 tentang Bea Perolehan Hak Atas Tanah dan Bangunan atau UU BPHTB. Perolehan hak atas tanah dan atau bangunan meliputi antara lain, karena pemindahan hak berupa: Jual beli, Tukar menukar, Hibah, Hibah wasiat, Waris, Pemasukan dalam perseroan atau badan hukum lain, lelang, Pelaksanaan putusan hakim yang mempunyai kekuatan hukum tetap, atau Penggabungan Perusahaan.

Dengan berlakunya UU PDRD, maka pengelolaan BPHTB yang semula menjadi pajak pusat dan dikelola oleh pemerintah pusat melalui Direktorat Jenderal Pajak dalam lingkungan Kementerian Keuangan, beralih menjadi pajak daerah dan dikelola oleh pemerintah daerah kabupaten/ kota melalui dinas pendapatan.

Dalam sistem pemungutan pajak secara umum di Indonesia, menganut sistem self assessment yaitu wajib pajak diberikan kepercayaan untuk dapat menghitung, memperhitungkan, dan membayar sendiri pajak yang terutang, sehingga melalui sistem ini pelaksanaan administrasi perpajakan diharapkan dapat dilaksanakan dengan rapi, terkendali, sederhana, dan mudah untuk dipahami oleh anggota masyarakat wajib pajak. ${ }^{10}$ Ciri-ciri Self Assessment System adalah: a. wewenang untuk menentukan besarnya pajak terhutang ada pada wajib pajak sendiri; b. wajib pajak aktif, mulai dari menghitung, menyetor dan melaporkan sendiri pajak yang terhutang; c. Fiscus tidak ikut campur dan hanya mengawasi. ${ }^{11}$

${ }^{10}$ Padmo Wahjono, Undang-Undang Perpajakan Beserta Penjelasan dan Peraturan Pelaksanaan, Ghalia Indonesia, Jakarta, 1984, hlm. 51.

11 Sri Pudiatmoko Y., Pengantar Hukum Pajak, Penerbit Andi Offset, Yogyakarta, 2002, hlm. 61. 
Kecuali terhadap pajak-pajak tertentu, seperti Pajak Bumi dan Bangunan, perhitungannya ditetapkan oleh pemerintah. Pemungutan BPHTB pada dasarnya dianut sistem self assessment, sehingga pihak yang memperoleh hak atas tanah dan bangunan sebagai wajib pajak harus menghitung, memperhitungkan, dan membayar sendiri pajaknya. Dengan demikian diperlukan adanya kesadaran dan kejujuran yang tinggi bagi masyarakat wajib pajak untuk melaksanakan kewajibannya dalam membayar pajak, dan diperlukan peran dari petugas pajak dalam melakukan pengawasan terhadap kepatuhan wajib pajak dalam membayar pajak, demikian pula dalam penerimaan dan pengelolaannya.

Dalam rangka pengawasan terhadap kepatuhan wajib pajak, sekaligus efektifitas dalam membayar pajak BPHTB dilakukan proses validasi oleh kantor pelayanan pajak daerah, yang semula juga dilakukan oleh kantor pelayanan pajak pusat melalui Kantor Pelayanan Pajak Pratama (KPP Pratama). Dalam proses validasi inilah petugas akan meneliti beberapa hal diantaranya tentang: kesesuaian obyek pajak dengan Nomor Obyek Pajak (NOP) atas tanah dan bangunan yang bersangkutan, kesesuaian antara subyek pajaknya, kesesuaian nilai transaksi yang digunakan sebagai dasar pengenaan pajak BPHTB. Dengan demikian dalam sistem pemungutan BPHTB tidak sepenuhnya menganut sistem self assessment. Dalam hal ini sekalipun wajib pajak diberi kepercayaan untuk dapat menghitung, memperhitungkan, dan membayar sendiri pajak yang terutang, ada kemungkinan campur tangan petugas pajak dalam menentukan nilai kewajaran. ${ }^{12}$ Dalam proses validasi tersebut apabila ada keraguan dari petugas pajak terhadap nilai transaksi yang digunakan sebagai dasar pengenaan BPHTB, ada kemungkinan dilakukan penelitian secara cermat, bila diperlukan diadakan peninjauan lokasi oleh petugas lapangan dengan mencari informasi nilai umum secara wajar dengan memperbandingkan NJOP atas tanah dan bangunan yang bersangkutan. Berdasarkan hasil validasi ada kemungkinan nilai yang diajukan sebagai dasar pengenaan BPHTB dilakukan perubahan sesuai dengan nilai transaksi yang sebenarnya secara wajar.

${ }^{12}$ Ratih Harinsari, Tjahjanulin Domai, Abdul Wachid, "Efektivitas Pemungutan Bea Perolehan Hak Atas Tanah dan Bangunan (BPHTB) Dalam Rangka Meningkatkan Pendapatan Asli Daerah (PAD) Kabupaten Kediri (Studi pada Dinas Pendapatan Kabupaten Kediri)", Jurnal Administrasi Publik (JAP), Vol 1, No. 2 April 2013, hlm. 268. 
Sebagaimana diatur dalam Pasal 87 UU PDRD, bahwa yang menjadi dasar pengenaan Bea Perolehan Hak atas Tanah dan Bangunan adalah Nilai Perolehan Objek Pajak. Arti Nilai Perolehan Objek Pajak sebagaimana dimaksud adalah nilai transaksi untuk peralihan karena jual beli atau nilai pasar untuk peralihan lainnya. Penggunaan nilai transaksi atau nilai pasar inilah yang menimbulkan ketidakpastian, karena nilai transaksi atau nilai pasar terhadap sebuah obyek itu bagi beberapa pihak sifatnya relatif, tergantung nilai itu bagi siapa, apakah bagi pihak-pihak, bagi petugas pajak, atau lainnya, sehingga sulit diperoleh nilai yang sama dan pasti. Padahal legalitas sebuah transaksi diperlukan adanya kebenaran dan kepastian hukum termasuk menyangkut nilai transaksi.

Adapun tarif pengenaan BPHTB bagi pembeli atau yang memperoleh hak terhadap semua transaksi peralihan tanah adalah sebesar 5\%.13 Dengan perhitungan: ( NPOP - NPOPTKP ) x $5 \%$.

Nilai Perolehan dikurangi Nilai Perolehan Tidak Kena Pajak (NPTKP) untuk wilayah Kabupaten/ Kota DIY sebesar Rp. 60.000.000,-14 kali tarif 5\%. Sebagai contoh sebuah transaksi dengan nilai perolehan sebesar Rp. 200.000.000,-. BPHTB yang harus dibayar adalah = Rp. 200.000.000,- - Rp. 60.000.000,- = Rp. 140.000.000,x 5\% = Rp 7.000.000,-. Disamping itu bagi penjual atau pihak yang mengalihkan dikenakan Pajak Penghasilan atas penjualan tanah dan bangunan dengan tarif sebesar 5\%, sehingga dengan nilai perolehan Rp. 200.000.000,- maka penjual akan dikenakan PPh sebesar $=200.000 .000,-$ x 5\% = Rp. 10.000.000,-.

Nilai perolehan inilah yang menentukan besar kecilnya BPHTB yang harus dibayar. Berdasarkan ketentuan undang-undang, maka nilai perolehan ini pada dasarnya adalah nilai transaksi, kecuali untuk peralihan tertentu seperti peralihan yang tidak diketahui berapa nilai transaksinya yaitu dengan mendasarkan NJOP PBB. Namun, di dalam praktek yang diperoleh dari hasil penelitian penggunaan dasar NJOP PBB akan sulit dapat diterima oleh petugas yang memvalidasi, kecuali karena waris atau hibah.

13 Pasal 88 ayat (1) Undang-Undang nomor 28 Tahun 2009 Tentang Pajak Daerah dan Retribusi Daerah, Lembaran Negara Republik Indonesia Tahun 2009, Nomor : 130.

${ }^{14}$ Atep Adya Barata, Bea Perolehan Hak. Atas Tanah dan Bangunan (BPHTB), Menghitung Obyek Pajak dan Cara Pengajuan Keberatan Pajak, PT Elex Media Komputindo, Kelompok Gramedia, Jakarta 2003, hlm. 19. Lihat Pasal 87 ayat (4) Undang-Undang nomor 28 Tahun 2009 Tentang Pajak Daerah dan Retribusi Daerah, Lembaran Negara Republik Indonesia Tahun 2009, Nomor : 130. 
Dalam hal validasi ini digunakan sebagai syarat dalam pendaftaran tanah, maka akan menjadi hambatan dalam proses pendaftaran peralihan tanah. Adanya hambatan dalam proses pendaftaran peralihan hak atas tanah ini tidak sesuai dengan harapan masyarakat, yang umumnya menghendaki proses yang cepat, sederhana dan biaya murah. Pelayanan aparat pelaksana pendaftaran tanah yang profesional dan transparansi dalam tata kerja serta biaya yang diperlukan, merupakan syarat keberhasilan pelaksanaan pendaftaran tanah. ${ }^{15}$

\section{Nilai Jual Obyek Pajak, Pajak Bumi dan Bangunan (NJOP PBB)}

Nilai Jual Objek Pajak Pajak Bumi dan Bangunan (NJOP PBB) merupakan dasar yang digunakan untuk menghitung Pajak Bumi dan bangunan (PBB). Dalam Pasal 79 ayat (1) Undang-Undang No. 28 Tahun 2009 tentang Pajak Daerah dan Retribusi Daerah (UU PDRD) NJOP ditetapkan untuk menghitung besarnya pajak terutang sesuai keadaan objek pajak pada setiap objek pajak yang ada diwilayahnya. Penentuan besarnya NJOP PBB dilakukan melalui proses penilaian tanah dan atau bangunan. Penilaian dilakukan dengan tujuan untuk menentukan NJOP tanah maupun bangunan per Meter persegi sebagai dasar pengenaan PBB pada tahun yang bersangkutan.

Dengan berlakunya UU PDRD maka kewenangan pemungutan dan pengelolaan PBB menjadi kewenangan daerah kabupaten/kota. NJOP PBB ditetapkan oleh Bupati/ Wali Kota melalui Peraturan Daerah (Bupati atau Walikota). NJOP tanah ditetapkan dengan satuan rupiah per meter persegi tanah sesuai lokasi tanah, yang tercermin dalam zona nilai tanah, sedangkan NJOP bangunan ditetapkan berdasar besarnya nilai per meter persegi dari biaya pembangunan bangunan yang bersangkutan. Perhitungan besarnya PBB terutang dalam satu tahun pajak dilakukan berdasarkan pada keadaan tanah dan/atau bangunan pada tanggal 1 Januari tahun pajak, sebagaimana diatur dalam Pasal 82 ayat (2) UU PDRD.

15 Maria S.W. Sumardjono, Kebijakan Pertanahan Antara Regulasi \& Implementasi, PT. Kompas Media Nusantara, Jakarta, 2002, hlm. 121-122. 
Pengenaan PBB dapat digolongkan kedalam sistem official assessment sytem yaitu wajib pajak akan terutang pajak setelah fiskus (pemda) menetapkan besarnya pajak terutang dan memberitahukan besarnya pajak terutang kepada wajib pajak dengan menggunakan surat yang biasanya disebut Surat Pemberitahuan Pajak Terutang Pajak Bumi dan bangunan (SPPT PBB).

Surat Pemberitahuan Pajak Terutang Pajak Bumi dan bangunan (SPPT $\mathrm{PBB})^{16}$ ini mempunyai fungsi sebagai pemberitahuan baik menyangkut besarnya PBB terutang yang ditetapkan oleh pemerintah daerah atas objek pajak yang dimiliki, dikuasai, dan/atau dimanfaatkannya, juga sebagai pemberitahuan tentang nilai tanah dan bangunan yang ditetapkan oleh pemerintah daerah sebagai dasar menghitung PBB.

NJOP ini selalu dievaluasi secara periodik berdasarkan situasi dan kondisi dan perkembangan wilayah yang bersangkutan oleh pemerintah daerah kabupaten/kota masing-masing wilayah. NJOP yang dimuat dalam Surat Pemberitahuan Pajak Terutang Pajak Bumi dan bangunan (SPPT PBB) dimaksud dibagikan kepada wajib pajak setiap tahun beberapa bulan sebelum jatuh tempo pembayaran PBB, yang biasanya pada awal tahun melalui bantuan aparat desa atau kalurahan masingmasing. Berikut beberapa tabel dari sebagian data hasil penelitian dari beberapa sumber tentang rentang nilai jual obyek pajak dengan nilai transaksi.

Tabel I

Beberapa Rentang Perbedaan NJOP dengan Nilai Transaksi

\begin{tabular}{|c|c|c|c|}
\hline No. & NJOP PBB (Rp.) per M2 & Nilai Transaksi (Rp.) per M2 & Kelipatan \\
\hline 1 & $335.000,-$ & 1.980.000,- & 5,9 . \\
\hline 2 & $335.000,-$ & $500.000,-$ & 1,4 \\
\hline 3 & $335.000,-$ & 1.300.000,- & 3,8 \\
\hline 4 & $702.000,-$ & 2.900.000,- & 4,1 \\
\hline 5 & 103.000,- & $350.000,-$ & 3,3 \\
\hline 6 & $48.000,-$ & 250.000 & 5,2 \\
\hline 5 & $243.000,-$ & 1.000.000,- & 4,1 \\
\hline 6 & 916.000,- & 4.500.000,- & 4,9 \\
\hline 7 & $285.000,-$ & 1.500.000,- & 5,2 \\
\hline
\end{tabular}

Sumber : Isian daftar pertanyaan dari dinas pendapatan daerah

16 Wiratni Ahmadi, Sinkronisasi Kebijakan Pengenaan Pajak Tanah Dengan Kebijakan Pertanahan di Indonesia, PT Refika Aditama, Bandung 2006, hlm. 139, juga lihat .Pasal 83 ayat (1) Undang-Undang nomor 28 Tahun 2009 Tentang Pajak Daerah dan Retribusi Daerah, Lembaran Negara Republik Indonesia Tahun 2009, Nomor : 130. 
Tabel II

Beberapa Rentang Perbedaan NJOP dengan Nilai Transaksi

\begin{tabular}{|c|c|c|c|c|}
\hline No. & NJOP PBB (Rp.) per M2 & Nilai Transaksi (Rp.) & per $\mathrm{M} 2$ & Kelipatan \\
\hline 1 & $500.000,-$ & & $600.000,-$ & 1,2 \\
\hline 2 & $64.000,-$ & & 120.000,- & 1,8 \\
\hline 3 & $150.000,-$ & & $300.000,-$ & 2 \\
\hline 4 & $50.000,-$ & & 150.000,- & 3 \\
\hline 5 & $300.000,-$ & & $600.000,-$ & 2 \\
\hline 6 & $350.000,-$ & & 650.000,- & 1,8 \\
\hline 5 & $150.000,-$ & & $250.000,-$ & 1,6 \\
\hline 6 & $25.000,-$ & & $125.000,-$ & 5 \\
\hline 7 & 200.000,- & & $500.000,-$ & 2,5 \\
\hline
\end{tabular}

Sumber : Isian daftar pertanyaan dari Masyarakat

Tabel III

Beberapa Rentang Perbedaan NJOP dengan Nilai Transaksi

\begin{tabular}{|r|r|r|r|r|}
\hline No. & Luas & $\begin{array}{c}\text { Nilai Transaksi (Rp.) } \\
\text { per Bidang }\end{array}$ & $\begin{array}{c}\text { NJOP PBB (Rp.) } \\
\text { per Bidang }\end{array}$ & Kelipatan \\
\hline 1 & 113 & $130.000 .000,-$ & $44.420 .000,-$ & 2,9 \\
2 & 146 & $65.000 .000,-$ & $33.478 .000,-$ & 1,9 \\
3 & 211 & $100.000 .000,-$ & $59.295 .000,-$ & 1,6 \\
4 & 610 & $75.000 .000,-$ & $62.830 .000,-$ & 1,1 \\
5 & 100 & $125.000 .000,-$ & $12.800 .000,-$ & 9 \\
6 & 213 & $120.000 .000,-$ & $42.000 .000,-$ & 2,8 \\
7 & 102 & $25.000 .000,-$ & $6.528 .000,-$ & 3,8 \\
8 & 101 & $12.500 .000,-$ & $2.727 .000,-$ & 4,5 \\
9 & 50 & $25.000 .000,-$ & $1.250 .000,-$ & 20 \\
\hline
\end{tabular}

Sumber : Isian daftar pertanyaan dari PPAT

Dari data dalam tabel tersebut, dapat diperoleh gambaran bahwa, secara umum bahkan dapat dikatakan hampir semuanya perbandingan antara nilai jual obyek pajak dalam SPPT PBB dengan nilai transaksi, adalah lebih tinggi nilai transaksi, bahkan terdapat beberapa yang selisihnya beberapa kali lipat. Data yang diperoleh dari Dinas pendapatan daerah dihitung berdasarkan laporan pembayaran BPHTB yang masuk dengan dasar nilai per meter persegi, demikian pula data yang diperoleh dari masyarakat dihitung berdasarkan hitungan per meter persegi. Sementara itu data yang diperoleh dari PPAT adalah data peralihan berdasarkan akta yang dibuat dengan nilai per bidang, karena dalam pembuatan 
akta PPAT tidak dihitung secara rinci harga per meter, tetapi merupakan keseluruhan nilai harga transaksi.

\section{Prosedur Penetapan Nilai Jual Obyek Pajak}

Dengan berlakunya UU PDRD maka penetapan nilai obyek pajak pada pajak bumi dan bangunan menjadi kewenangan pemerintah daerah kabupaten/kota sesuai wilayahnya, sehingga masing-masing daerah dapat berbeda cara maupun waktu penetapannya yang secara periodik mengadakan evaluasi tentang NJOP. Nilai jual obyek pajak ini ditetapkan memang dimaksudkan untuk menghitung besarnya pajak terutang pada pajak bumi dan bangunan, sehingga tidak sama dengan nilai pasar atau pun nilai transaksi di masyarakat.

Nilai transaksi misalnya dalam jual beli itu merupakan nilai yang menjadi kesepakatan dan yang akan dibayarkan antara pembeli dan penjual dalam suatu transaksi jual beli. Oleh karena nilai transaksi ini merupakan kesepakatan antara para pihak yang melakukan transaksi, maka sangat subyektif dan dimungkinkan setiap pihak yang melakukan jual beli dapat terjadi perbedaan nilai yang disepakati, termasuk dapat berbeda pula pendapat petugas yang melakukan validasi. Penentuan nilai memang bersifat subyektif, tergantung kepentingan siapa, apakah kepentingan pihak-pihak dalam sebuah transaksi, atau kepentingan pemerintah dalam menentukan besarnya pajak yang harus dibayar wajib pajak. Dengan demikian penggunaan nilai transaksi sebagai dasar perhitungan ВРНTB terjadi ketidakpastian jumlah kewajiban wajib pajak yang harus dibayar.

Dalam sebuah transaksi nilai tanah berbeda-beda tergantung dan dipengaruhi pada beberapa hal, bisa luasnya, letak tanah, bentuk bidangnya. Misalnya sebidang tanah yang letaknya di pinggir jalan nilainya pasti berbeda dengan sebidang tanah yang letaknya di dalam gang.

Pemerintah daerah kabupaten/kota dalam menetapkan nilai jual obyek pajak tanah per meter dilakukan melalui proses penilaian tanah dengan cara pendekatan atau metode, yaitu Pendekatan dengan perbandingan harga atas obyek lain yang sejenis, pendekatan nilai perolehan baru, dan pendekatan nilai jual 
pengganti, yaitu metode penentuan nilai jual suatu obyek pajak yang didasarkan pada hasil produksi obyek pajak yang bersangkutan. ${ }^{17}$

Dalam pendekatan dengan perbandingan didasarkan pada nilai pasar, adalah nilai tanah sebagai objek yang akan dinilai, dan dihitung berdasarkan analisis perbandingan dan penyesuaian terhadap tanah sejenis yang telah diketahui harga pasarnya, melalui informasi yang diperoleh beberapa pihak dan dengan cara atau metode tertentu. Harga pasar tanah pembanding diperoleh dari transaksi jual beli ataupun penawaran atas tanah yang berada diseputaran tanah yang akan dinilai. Kalau tanahnya merupakan komplek perumahan relatif lebih mudah, karena biasanya melalui pengembang ada brosur-brosur iklan penawaran harga yang bisa digunakan sebagai patokan. Tanah sejenis disini mengandung pengertian sejenis dalam hal penggunaan, keadaan, lokasi dan lainnya. Selain itu sumber data harga pasar tanah dapat diperoleh dari pembeli atau penjual, notaris PPAT, makelar, perangkat daerah dan sumber lainnya yang dapat dipercaya.

Dengan dasar data harga pasar tanah yang diperoleh, selanjutnya penilai akan melakukan analisis perbandingan dan penyesuaian nilai obyek pajak tanah dan bangunan yang bersangkutan. Perbandingan dilakukan dengan membandingkan beberapa faktor yang signifikan dapat berpengaruh terhadap nilai tanah. Faktor signifikan yang dapat berpengaruh terhadap nilai tanah antara lain lokasi tanah, fisik dan penggunaan tanah. ${ }^{18}$ Lokasi tanah berkaitan dengan letak posisi tanah dengan kondisi lingkungan di wilayah di sekitar tanah. Sementara fisik tanah berkaitan dengan keluasan, lebar depan, kondisi tanah, bentuk, penggunaan tanah dan lainnya yang melekat pada bidang tanah masing-masing.

Dalam menentukan NJOP dilakukan untuk mendapatkan harga pasar yang wajar pada kondisi tertentu setidaknya dalam satu tahun pajak yang bersangkutan. Harga pasar yang wajar digambarkan dari harga rata-rata yang diperoleh dari transaksi jual beli yang terjadi secara wajar, perbandingan harga dengan objek lain yang sejenis yang letaknya berdekatan dan telah diketahui harga jualnya. ${ }^{19}$ Setidaknya dengan memperhatikan harga tanah-tanah yang letaknya tidak terlalu

${ }^{17}$ Ibid., hlm. 42

${ }^{18}$ Wawancara dengan Bapak Anggit Nur Hidayat, dari DPPKAD Kabupaten Bantul, pada tanggal 10 Juni 2015.

19 Ovelia Veradina Imbing, "Analisis Penetapan NJOP dan Implikasinya terhadap Penerimaan PBB di Kota Manado”, Jurnal Riset Ekonomi, Manajemen, Bisnis dan Akuntansi (EMBA) Vol. 1 No. 3 Juni 2013, hlm. 488 
jauh dengan tanah yang akan ditetapkan NJOP nya. NJOP merupakan harga ratarata yang diperoleh dari transaksi jual beli (market value). Jika tidak terdapat transaksi jual beli, NJOP ditentukan melalui perbandingan dengan harga obyek lain yang sejenis, yang letak serta fungsinya sama. ${ }^{20}$

Untuk penentuan dan penyesuaian NJOP dilakukan analisis perbandingan dan penyesuaian paling tidak dengan tiga data harga pasar atas beberapa tanah yang sesuai sebagai data pembanding untuk memperoleh nilai yang wajar. Untuk mendapatkan nilai yang mencerminkan harga pasar yang wajar data harga tanah yang digunakan sebagai pembanding diperoleh dari data transaksi yang baru saja terjadi atas tanah yang sesuai dan letaknya tidak terlalu jauh dari tanah yang dinilai..21 Di samping itu data nilai tanah yang digunakan sebagai pembanding harus data yang sejenis. Dalam arti meskipun tanah tersebut sama-sama tanah pekarangan, namun tanah yang dipakai sebagai data pembanding harus mempunyai jenis penggunaan yang sama dengan tanah yang akan dinilai, misalnya sama-sama untuk, rumah tinggal, perumahan atau kegiatan usaha dan lainnya.

Berdasarkan hasil Focus Group Discussion (FGD) dari keterangan yang disampaikan wakil dari DPPKAD Kabupaten Bantul prinsipnya dalam menentukan perubahan NJOP tidak serta merta begitu saja dinaikkan, tetapi menggunakan perbandingan antara lain, menggunakan nilai transaksi yang wajar disekitar lokasi tanah, pendapatan masyarakat, sedang untuk perumahan dapat pula menggunakan perbandingan harga yang ditawarkan dalam brosur. Kemudian dalam menentukan besarnya kenaikan NJOP biasanya hanya dinaikkan nilai satu kelas atau tingkatan. DPDPK Kota Yogyakarta menyampaikan bahwa dasar kenaikan NJOP, dengan mengumpulkan nilai-nilai transaksi, dan dibuat Nilai Zona yang dibagi menjadi tiga bagian, kemudian di rata-rata untuk menentukan kenaikan NJOP PBB. 22

Dalam penilaian untuk menetapkan NJOP tanah per $\mathrm{M}^{2}$, permasalahan yang dihadapi pemerintah daerah di lapangan adalah banyaknya jumlah objek pajak yang harus dinilai dalam waktu atau tanggal penilaian yang sama serta jumlah penilai yang terbatas. Untuk mengatasi permasalahan itu telah dikembangkan cara

${ }^{20}$ Wiratni Ahmadi, Op. Cit., hlm. 142.

${ }^{21}$ Hasil diskusi dalam Focus Group Discussion (FGD) 4 Agustus 2015.

${ }^{22}$ Keterangan bapak Anggit Nur Hidayat, dari DPPKAD Kabupaten Bantul, dalam Focus Group Discussion (FGD) 4 Agustus 2015. 
penilaian masal. Penilaian masal dilakukan untuk menilai beberapa objek atau bidang tanah dalam satu proses penilaian. Alternatif dalam penentuan NJOP bisa juga dilakukan berdasarkan kesepakatan atau kompromi yang bisa diambil, adalah dengan kerjasama antara aparat kantor pertanahan dan DPPKAD melalui peta zona nilai tanah (ZNT) yang dapat dipergunakan dalam penentuan NJOP dan melakukan sosialisasi kepada masyarakat. ${ }^{23}$

\section{Beberapa Alternatif Nilai sebagai Dasar Perhitungan ВРНTB}

Dari hasil penelitian diperoleh keterangan bahwa pada dasarnya dalam pelaksanaan pembayaran BPHTB dalam transaksi peralihan tanah termasuk jual beli tetap mengunakan dasar perhitungan sesuai dengan UU, seperti untuk jual beli menggunakan dasar nilai transaksi. Nilai transaksi dalam peralihan jual beli dicantumkan dalam akta jual beli, sehingga nilai inilah yang digunakan sebagai dasar perhitungan pembayaran BPHTB. Hanya saja dengan adanya proses validasi atau penelitian oleh petugas yang berwenang, maka belum tentu nilai yang digunakan dasar menghitung BPHTB oleh pihak-pihak dalam jual beli ini diterima. Dari hasil validasi ini ada beberapa kemungkinan, bisa saja diterima, bisa juga tidak diterima sehingga terdapat kurang bayar. Adanya kurang bayar menurut petugas validasi ini harus dilakukan penambahan pembayaran, dan dengan sendirinya nilai dasar perhitungan yang juga sebagai harga transaksi akan berubah.

Bea Perolehan Hak Atas Tanah dan Bangunan (BPHTB) yang dikenakan kepada pihak yang memperoleh hak atas tanah karena peralihan hak sering kali menimbulkan permasalahan antara wajib pajak yaitu pihak yang memperoleh hak atas tanah dengan Dinas Pendapatan Daerah selaku pihak yang memungut BPHTB. Permasalahan yang muncul adalah karena adanya perbedaan besaran jumlah ВРНTВ yang harus dibayar.Perbedaan ini karena nilai transaksi yang digunakan sebagai dasar menghitung besarnya BРНTB oleh wajib pajak kadang kala tidak sesuai dengan penilaian petugas dinas pajak yang berwenang. Dari perbedaan tersebut tidak jarang petugas pajak dalam proses verifikasi/ validasi,

${ }^{23}$ Priyo Katon Prasetyo, Interaksi Kepentingan Dalam Penentuan Bea Perolehan Hak Atas Tanah, Jurnal Agraria dan Pertanahan, Volume 1, No. 1, 2015, hlm. 81. 
meminta agar nilai transaksi dirubah dan disesuaikan menurut penilaian petugas pajak. Sehingga menimbulkan ketidakpastian baik nilai transaksi maupun besarnya pajak yang harus dibayar wajib pajak. Ketidakpastian ini dapat menimbulkan berbagai konsekuensi hukum, antara lain apabila terjadi sengketa dapat mengakibatkan transaksinya menjadi tidak sah dan bahkan menjadi batal apabila nilai transaksinya ternyata tidak sesuai dengan kenyataan yang sebenarnya.Di samping itu dapat merugikan masyarakat, karena harus membayar pajak yang lebih tinggi dari yang seharusnya. Penggunaan nilai transaksi sebagai dasar perhitungan BРHTB yang memerlukan validasi, menimbulkan prosedur yang rumit dan panjang, bahkan dapat menghambat proses peralihan tanah.

Dari data dan ketengan penelitian dapat dijelaskan bahwa pada umumnya masyarakat tidak mengetahui dan memahami tentang adanya kewajiban pembayaran BPHTB dalam transaksi (jual beli) tanah. Para pihak biasanya tidak mengurus sendiri dalam pelaksanaan kewajiban membayar BРHTB tersebut, tetapi umumnya diserahkan kepada notaris-PPAT, baik dalam perhitungan dan pembayarannya. Nilai yang digunakan sebagai dasar perhitungan pada umumnya masyarakat menginginkan pembayaran yang ringan, sehingga terjadi penurunan harga yang tidak sesuai dengan kenyataan, akibatnya sering terjadi perbedaan antara perhitungan dari wajib pajak dengan pejabat dinas yang berwenang dalam hal dilakukan validasi.

Ada beberapa nilai alternatif yang dapat digunakan sebagai dasar perhitungan BPHTB antara lain: 1. nilai pasar sebagai nilai umum anggapan masyarakat di lokasi tanah yang bersangkutan; 2. nilai transaksi, yaitu nilai yang digunakan sebagai kesepakatan para pihak dalam sebuah transaksi, misalnya dalam jual beli, dan biasanya kalau dalam jual beli nilai tersebut akan tercantum dalam akta jual beli; 3. nilai Jual Obyek Pajak (NJOP) yang tercantum dalam Surat Pemberitahuan Pajak Terutang Pajak Bumi Dan Bangunan (SPPT PBB). NJOP PBB ini selalu ditinjau secara periodik mengenai besarannya dengan berdasarkan perkembangan nilai yang dipengaruhi oleh kondisi perkembangan wilayahp; 4 . Zona Nilai Tanah (ZNT), nilai ini ditetapkan oleh kantor Pertanahan setempat dan dipergunakan sebagai dasar menghitung berapa besar Penerimaan Negara Bukan Pajak (PNBP) untuk pendaftaran peralihan hak ata stanah. ZNT ini juga selalu di 
tinjau secara periodik dengan memperhatikan dan menyesuaikan perkembangan nilai tanah pada wilayah tanah yang bersangkutan.

Secara umum rentang atau perbandingan nilai di antara nilai-nilai tersebut, yaitu nilai pasar, nilai transaksi, NJOP PBB, maupun ZNT tersebut nilai yang tertinggi adalah nilai transaksi, kemudian nilai dalam ZNT, dan kemudian nilai yang paling rendah adalah NJOP PBB. Nilai transaksi sebagai nilai yang paling tinggi adalah wajar karena nilai transaksi ditentukan oleh pihak-pihak berdasarkan kesepakatan antara pihak-pihak seperti dalam jual beli dan sifatnya subyektif dengan terjadinya tawar menawar, sehingga berpengaruh terhadap tingginya nilai. Sementara itu, nilai dalam ZNT dan NJOP PBB relatif lebih rendah karena ditentukan secara periodik hanya dalam waktu tertentu, yang kemungkinan tertinggal dengan perkembangan nilai yang terjadi, akibat dari perkembangan nilai tanah yang selalu berubah dan juga dipengaruhi oleh lokasi letak tanah.

Dari perbedaan nilai tersebut seharusnya ada kepastian nilai mana yang digunakan sebagai dasar menghitung BPHTB, dan juga ada kepastian tentang berapa besar BPHTB yang harus dibayar. Agar memperoleh kepastian tentang berapa BPHTB yang harus dibayar, diantara beberapa nilai tersebut yang paling tepat adalah dengan menggunakan dasar NJOP PBB. Hal ini didasarkan atas beberapa pertimbangan antara lain : a. nilai tersebut ditentukan oleh instansi pemerintah; b. mempermudah dalam menghitung dan membayar BPHTB; c. jumlah BPHTB yang harus dibayar sudah pasti, sehingga tidak diperlukan validasi atau penelitian yang berkait dengan nilai; d. Prosedur yang sederhana dan efisien, sehingga mempermudah dan memperlancar proses pendaftaran peralihan.

Dari pertimbangan tersebut sudah seharusnya ada kepastian nilai yang digunakan untuk perhitungan BPHTB yaitu dengan menggunakan dasar NJOP PBB. Dengan adanya kepastian nilai yang digunakan sebagai dasar perhitungan BPHTB tersebut akan memudahkan dan mempercepat wajib pajak dalam membayar BPHTB dan melakukan proses pendaftaran peralihan tanah. 


\section{Penutup}

Dari data dan keterangan sementara yang diperoleh dalam penelitian dapat disusun kesimpulan sebagai berikut, pertama, perbedaan rentang nilai traksaksi dengan nilai NJOP dalam SPPT PBB, pada umumnya nilai transaksi lebih tinggi dari NJOP PBB yang tercantum dalam SPPT PBB. Kedua, alternatif pilihan nilai yang sesuai untuk digunakan sebagai dasar menghitung BPHTB adalah NJOP PBB yang tercantum dalam SPPT PBB untuk memudahkan dan mempercepat wajib pajak dalam membayar BPHTB dan melakukan proses pendaftaran peralihan tanah.

\section{Daftar Pustaka}

Ahmadi, Wiratni, Sinkronisasi Kebijakan Pengenaan Pajak Tanah Dengan Kebijakan Pertanahan di Indonesia, PT Refika Aditama, Bandung 2006.

Al Rashid, Harun, Sekilas Tentang Jual Beli Tanah (Berikut Peraturan-peraturannya), Ghalia Indonesia, Jakarta, 1987.

Barata, Atep Adya, Bea Perolehan Hak Atas Tanah dan Bangunan (BPHTB), Menghitung Obyek Pajak dan Cara Pengajuan Keberatan Pajak, PT Elex Media Komputindo, Kelompok Gramedia, Jakarta 2003.

Harinsari, Ratih, Tjahjanulin Domai, Abdul Wachid, Efektivitas Pemungutan Bea Perolehan Hak Atas Tanah dan Bangunan (BPHTB) Dalam Rangka Meningkatkan Pendapatan Asli Daerah (PAD) Kabupaten Kediri (Studi pada Dinas Pendapatan Kabupaten Kediri), Jurnal Administrasi Publik (JAP), Vol 1, No.2 April 2013.

Harsono, Budi, Hukum Agraria Indonesia, Djambatan, Jakarta, 2007.

Imbing, Ovelia Veradina, Analisis Penetapan NJOP dan Implikasinya Terhadap Penerimaan PBB di Kota Manado, Jurnal Riset Ekonomi, Manajemen, Bisnis dan Akuntansi (EMBA) Vol. 1 No. 3 Juni 2013.

Jeddawi,Murtir, Implementasi Kebijakan Otonomi Daerah (Analisis Kewenangan, Kelembagaan, managemen Kepegawaian, dan Peraturan Daerah), Total Media, Yogyakarta, 2008.

Prasetyo, Priyo Katon, Interaksi Kepentingan Dalam Penentuan Bea Perolehan Hak Atas Tanah, Jurnal Agraria dan Pertanahan, Volume 1, No. 1, 2015, hlm. 74-83.

Pudiatmoko, Sri Y, Pengantar Hukum Pajak, Penerbit Andi offset, Yogyakarta, 2002.

Sumardjono, Maria S.W, Kebijakan Pertanahan Antara Regulasi E Implementasi, PT. Kompas Media Nusantara, Jakarta, 2002.

Suratman, dan Philips Dillah, Metode Penelitian Hukum, Alfabeta, Bandung, 2012. 
Sutedi, Adrian, Hukum Pajak dan Retribusi Daerah, Ghalia Indonesia, Bogor. 2008.

Wahjono, Padmo, Undang-Undang Perpajakan Beserta Penjelasan dan Peraturan Pelaksanaan, Ghalia Indonesia, Jakarta.

Waluyo, Bambang, Penelitian Hukum Dalam Prak, 1984tek, Sinar Grafika, Jakarta, 1991.

Undang-Undang Republik Indonesia No. 21 Tahun 1997 Tentang Bea Perolehan Hak Atas Tanah dan Bangunan (Lembaran Negara Republik Indonesia Tahun 1997 No. 3688)

Undang-Undang Republik Indonesia No. 20 Tahun 2000 tentang Perubahan Atas Undang-Undang Nomor 21 Tahun 1997 Tentang Bea Perolehan Hak Atas Tanah Dan bangunan (Tambahan Lembaran Negara Republik Indonesia No. 9)

Undang-Undang Republik Indonesia No. 28 Tahun 2009 tentang Pajak Daerah dan Retribusi Daerah (Tambahan Lembaran Negara Republik Indonesia No. 5049). 